\title{
Calycomyza hyptidis Spencer (Diptera, Agromyzidae): descriptions, redescriptions and first record in Ocimum basilicum (Lamiaceae) in Brazil
}

\author{
Viviane Rodrigues de Sousa ${ }^{1,2} \&$ Márcia S. Couri ${ }^{1,3}$
}

\begin{abstract}
1Departamento de Entomologia, Museu Nacional,20940-040 Rio de Janeiro-RJ, Brazil. sousavrodrigues@gmail.com, courimarcia@gmail.com ${ }^{2} \mathrm{PIBIC} / \mathrm{UFRJ}$

${ }^{3}$ Scholarship CNPq fellow.
\end{abstract}

\begin{abstract}
Calycomyza hyptidis Spencer (Diptera, Agromyzidae): descriptions, redescriptions and first record in Ocimum basilicum (Lamiaceae) in Brazil. All phases of the leafminer Calycomyza hyptidis Spencer are for the first time described, including the larva, puparium and adult female. Illustrations are presented for male and female terminalia, mine, larva and pupa. The species is first recorded in leaves of Ocimum basilicum L. (Lamiaceae) in Brazil.
\end{abstract}

KEYWORDS. Economic importance; leafminer; morphology; new record.

Calycomyza Hendel (Diptera, Agromyzidae) is a genus with a little more than 60 species in the Neotropical region (Boucher 2010), 21 of them recorded from Brazil (Spencer 1967; Martinez \& Etienne 2002). Species of this genus are characterized for the distinct and contrasting coloration, usually with scutum black and notopleuron yellow. The presence of large and wide spines on male epandrium is also characteristic. The larvae are leafminers; some of them show a high degree of specificity, while others are oligophagous (Spencer 1973b).

Calycomyza hyptidis Spencer was originally described from Florida in Hyptis pectinata L. (Lamiaceae) by Spencer (1966). Three years before, Spencer (1963) described the male of Calycomyza allecta (described by Melander (1913) based on females), based on two males from Brazil, one from Santos (São Paulo), miner in Bidens pilosa L. (Asteraceae), and the other from Nova Teutônia (Santa Catarina) with no reference to the host plant. The illustrated terminalias of the two males are completely distinct from each other, as it can be seen in Figs. 52a,b and 53a,b of Spencer (1963: 338). Spencer \& Stigmaier (1973: 74-75) made reference to these illustrations arguing the following: "It now seems clear that the specimen from Brazil, Nova Teutonia, tentatively referred to $C$. allecta s. lat (Spencer 1963 Fig. 53a) represents hyptidis. The species presumably occurs in central America and the Greater Antilles, from where it has reached southern Florida". Under C. allecta they wrote (p. 182): "With only females available in the type series, there has been uncertainty about the exact status of this species. Spencer (1963: Figs. 52-53) illustrated entirely different aedeagus of two specimens from Brazil, which appeared to represent this species. However, with no males available from the general type locality, it was uncertain which was the true allecta. The aedeagus of the specimen now seen from Dominica agrees almost exactly with the specimen "ex Bidens pilosa" from Santos, Brazil and it can therefore now be accepted that this represents the true allecta (=lateralis Williston)". So, the males represented by Spencer (1963) truly refer to C. hyptidis (Fig. 53) and to C. allecta (Fig. 52). Spencer \& Stigmaier (1973) also recorded in the same paper C. hyptidis in Hyptis pectinata (Lamiaceae).

In Costa Rica C. hyptidis was recorded in Hyptis capitata Jacq. (Spencer 1983) and more recently, Esposito (1994) recorded it from Marajó Is. (Pará, Brazil), as a leaf miner in Hyptis mutabilis (Rich.) Briq. and presented an illustration of the male aedeagus and of the mine. Spencer et al. (1992) recorded $C$. hyptidis miner in $H$. capitata, $H$. pectinata, Ocimun basilicum L. and Salvia sp from Guadalupe. In Venezuela $C$. hyptidis was recorded from Hyptis sp., O. basilicum and Salvia sp. forming an irregular star-shaped mine (Spencer 1973b).

Until now, all known host records for $C$. hyptidis in Brazil belong to the genus Hyptis Jacq. This genus has about 300 species with a wide geographical distribution in the tropical areas of Americas and Africa. In northeastern Brazil $H$. pectinata and Hyptis suaveolens (L.), commonly known respectively as "alfazema-brava" and "alfazema-de-caboclo", are used in popular medicine (Basílio et al. 2006) while $H$. mutabilis has medicinal use.

We are recording for the first time $C$. hyptidis in another genus of the same plant family Lamiaceae. This large family has a world-wide distribution, with about 7,780 species described in 295 genera (Stevens 2001). It has many important species with different uses as medicine, cosmetics (through the extraction of essential oils) and also as condiments (Mentha L., Lavandula L., Marrubium L., Nepeta L., Ocimum L., Origanum L., Rosmarinus L., Salvia L., Satureja L., Thymus L.), among others. Other many species have a decorative potential and some species of Leonotis R.Br. (Africa) and Leonurus L. (Europe and Asia) are invasive in agricultural cultures. 


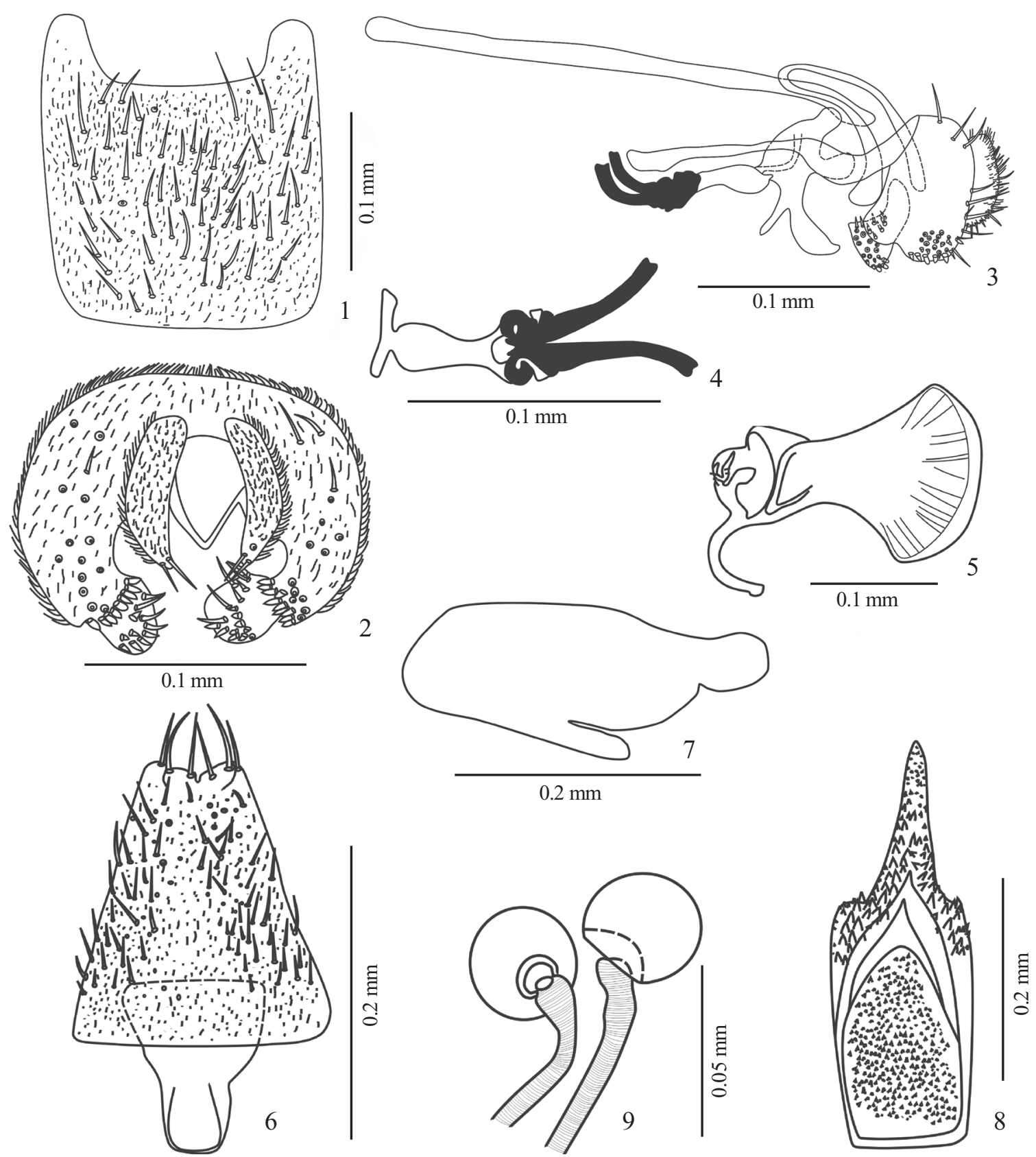

Figs. 1-9. Calycomyza hyptidis: 1, male, sternite 5; 2, cercal plate, dorsal view; 3, male terminalia, lateral view; 4, aedeagus, ventral view; 5, ejaculatory apodeme, dorsal view; 6, female, segment 7, dorsal view; 7, segment 7, lateral view; 8, segment 9, dorsal view; 9, spermatheca.

The new host plant, Ocimum basilicum, is a culinary herb used in many cuisines, commonly known as basil. There are some known pathogens, including fungi, that can attack this plant causing damage to the crop, and this new record may be highly significant considering the economic importance of this plant.

Some other species of Agromyzidae have been recorded as pests in the same plant family Lamiaceae, such as Phytomyza petoei (Hering, 1924) which occurrs in Mentha longifolia (L.) and Mentha spicata L., and Phytomyza horticola (Goureau, 1851) in Mentha spp. (Spencer 1973a). Spencer (1990) recorded Calycomyza menthae, Liriomyza strigata, Liriomyza trifolii and Phytomyza platensis miners in plants of the genus Ocimum.

This paper also gives description and illustrations of all phases of $C$. hyptidis.

\section{MATERIAL AND METHODS}

Small branches with leafs of Ocimum basilicum L. with mines and larva (Figs. 2-3) were collected in Rio de Janeiro (Barra da Tijuca) and transferred to the Diptera laboratory at Museu Nacional, Universidade Federal do Rio de Janeiro. The branches were placed in small vials with water and sugar 
which were placed inside plastic pots covered with tissue (Fig. 4) until the emergence of the adults. The plant was in a garden and about $50 \%$ of it leafs were infested by the mines.

The larvae were clarified in $10 \%$ potassium hydroxide for 24 hours, and afterwards treated with acetic acid, 70\% alcohol, absolute alcohol, then fixed with butyl acetate and mounted on slides and coverglass. The adults were mounted on entomological pins. Male and female terminalia were clarified with $10 \%$ potassium hydroxide and placed on slides with glycerin before dissection. The illustrations of the leaf and the pupa were made using a stereomicroscope and the larvae and terminalia using an optic microscope, both with camera lucida. The terminology follows McAlpine (1981), except for "postpedicel", used for "antennal flagellomere", following Stuckenberg (1999).

\section{TAXONOMY}

\section{Calycomyza hyptidis (Spencer, 1966)}

Male. Body length. 1.4-1.5 mm. Wings. 1.5-1.6 mm. General coloration. Frons and face yellow; fronto-orbital plate yellow and slightly darkened to upper ors; ocellar triangle shining black, ocellus yellow; lunule yellow; antenna and arista black; gena yellow; palpus black; proboscis yellow; mesonotum shining black, with a contrasting yellow lateral band on postpronotal lobe, notopleuron and part of anepisternum and anepimeron; halter yellow; calypter light yellow, with margin and fringe black; legs black, with fore femuro-tibial joint yellow; abdomen shining black; pulvilli light yellow.

Head. Four pairs of fronto-orbital setae, the two upper ones stronger than the two lower ones; ocellar setae thin and medium size, forward directed; postocellar setae divergent, stronger and longer than the ocellar pair, inner vertical setae long and convergent; outer vertical setae a little shorter than the inner and divergent; postpedicel rounded minutely pubescent; arista long, with short cilia; vibrissa short and strong; palpus and proboscis with long cilia.

Thorax. Acrostichals not differentiated; dorsocentrals 0:2; postpronotal 1; notopleurals 2; supralars 2; intralars 2; katepisternals $0: 1$; anepisternals 4 ; pre-scutellars absent; scutellum with a long pair of basal and apical setae.

Abdomen. Sternite 5 large, with setae on almost the whole surface (Fig. 1).

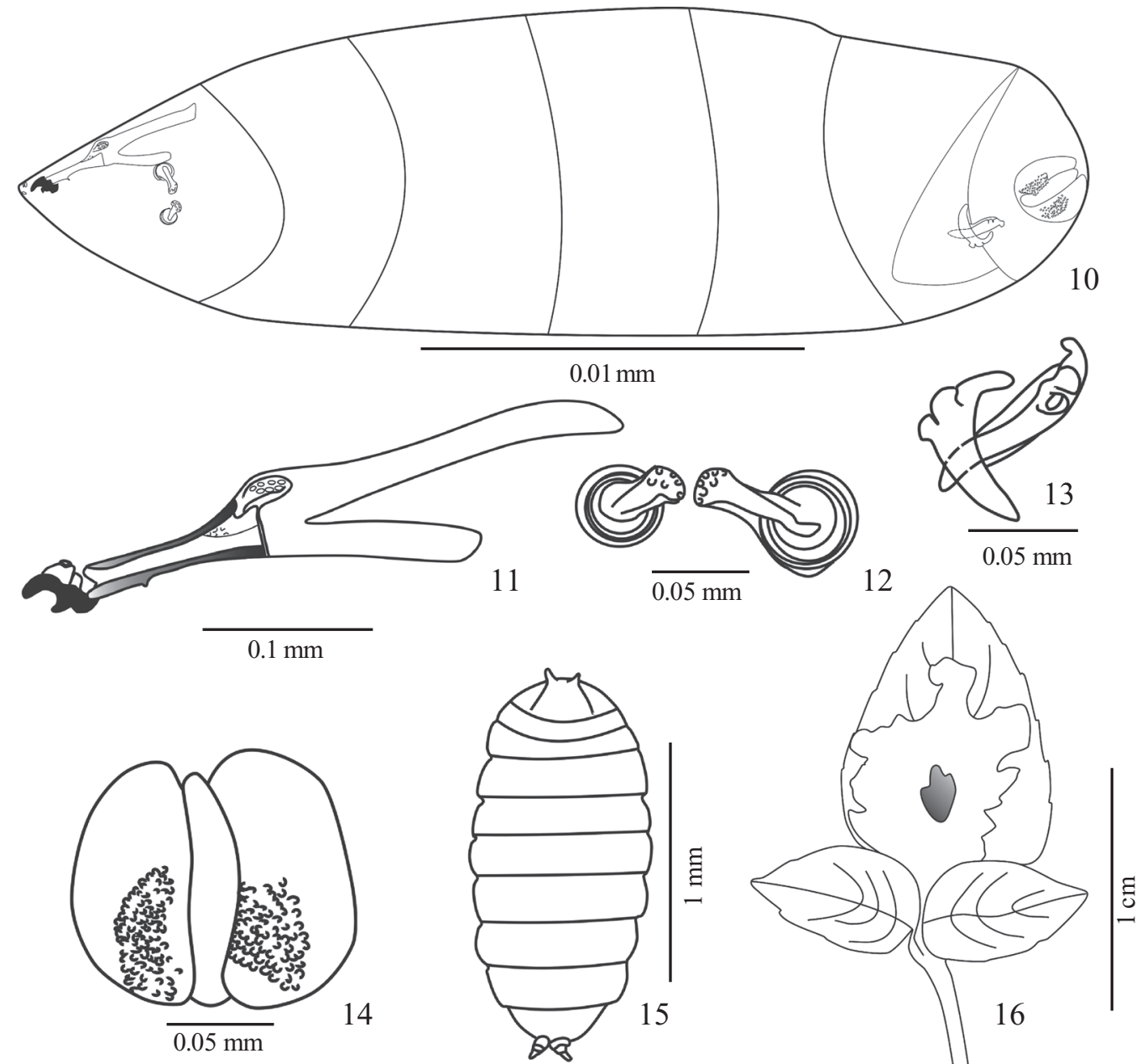

Figs. 10-16. Calycomyza hyptidis: 10, Larvae; 11, cephalo-pharingeal skeleton; 12, anterior spiracles of larva; 13, posterior spiracles of larva; 14, anal region of larva; 15 , puparium; 16, host plant. 
Terminalia. Hypandrium large with conspicuous patch of spines at apex, cercal plate long with two setae at apex and many cilia on entire surface; surstylus with short and long spines (Figs. 2-3); aedegus with distiphallus long and bifurcate and basiphallus rounded (Figs. 3-4); ejaculatory apodeme moderately enlarged (Fig. 5).

Female. Similar to male.

Ovipositor. Segment 7 large with long setae (Figs. 6-7); segment 9 long with spines (Fig. 8); spermathecae rounded; sperm ducts with pleated aspect (Fig. 9).

Larvae. (Fig. 10). General color yellow. Cephalopharyngeal skeleton with simple mandible (Fig. 11); anterior spiracles with seven pores, two well defined (Fig 12); posterior spiracles with three digitiform projections (Fig. 13); anal region with ornamentation (Fig. 14).

Puparium. General color brownish, shape as in Fig. 15.

Host plant. Ocimum basilicum (Lamiaceae), first record for Brazil. Mine expanded forming a bubble (Fig. 16).

Comment. As already stated by Spencer (1973b) this species is oligophagous, occurring on several genera of Lamiaceae. Pupation occurs outside of the mine, in the ground. The adult male can be easily identified by the characteristic terminalia, especially the aedeagus.

Material examined. Brazil, Rio de Janeiro, Barra da Tijuca, 02.x.2011 and 19. xii.2011, Couri, M.S. coll., 2 males, 1 female, 1 larvae, 3 pupae.

\section{ACKNOWLEDGMENTS}

We are grateful to Dr. Rachel Alexandre de Carvalho (Museu Nacional - Universidade Federal do Rio de Janeiro), for the help with the Automontage photographs. MSC is grateful to Conselho Nacional de Desenvolvimento Cientifico e Tecnológico (CNPq, process 3013012007-7) for the financial support and VRS for the PIBIC/UFRJ scholarship.

\section{REFERENCES}

Boucher, S. 2010. Agromyzidae (Leaf-mining Flies), p. 1057-1071. In: Brown, B.V., Borkent, A., Cumming, J.M., Wood, D.M., Woodley, N.E.
\& Zumbado, M.A. (eds.). Manual of Central American Diptera, Vol. 1. Ottawa, NRC Research Press, 1343 p.

Basílio, I.J.L.D., Agra, M.F., Rocha, E.A., Leal, C.K.A. \& Abrantes, H.F. 2006. Estudos farmacobotanicos comparativo das folhas de Hyptis pectinata (L.) Poit. e Hyptis suaveolens (L.) Poit. (Lamiaceae). Acta Farmaceutica Bonaerence 25: 518-25

Esposito, M.C. 1994. Species of Calycomyza Hendel (Diptera, Agromyzidae) from Marajo Island, Para, Brazil, including a new species. Boletim do Museu Paraense Emilio Goeldi (Ser. Zool.) 10: 113-118.

McAlpine, J.F. 1981. Morphology and terminology - adults, p. 9-63. In: McAlpine, J. F., Peterson, B.V., Shewell, G.E., Teskey, H.J., Vockeroth, J.R. \& Wood, D.M. (eds.), Manual of Nearctic Diptera, Vol. 1, Monograph 27, Ottawa, Research Branch Agriculture Canada, 674 p.

Martinez, M. \& Etienne, J. 2002. Liste systématique et biogéographique dês Agromyzidae (Diptera) de la région néotropicale. Bollettino di Zoologia Agraria e di Bachicoltura (Ser. II) 34: 25-52.

Melander, A.L. 1913. A synopsis of the dipterous groups Agromyzinae, Milichiinae, Ochthiphilinae, and Geomyzinae. Journal of the New York Entomological Society 21: 219-300.

Spencer, K.A. 1963. A synopsis of the Neotropical Agromyzidae (Diptera). Transactions of the Royal Entomological Society of London 115: 291-389.

Spencer, K.A. 1966. New and interesting Agromyzidae (Diptera) from Florida. Stuttgarter Beitrage zur Naturkunde 158: 1-20.

Spencer, K.A. 1967. 83. Agromyzidae. In: A catalogue of the Diptera of the Americas South of the United States. São Paulo, Departamento de Zoologia, Secretaria da Agricultura, 23 p.

Spencer, K.A. 1973a. Agromyzidae (Diptera) of economic importance. Series Entomologica, Vol. 9. The Hague, Dr. W. Junk B.V., 418 p.

Spencer, K.A. 1973b. The Agromyzidae (Diptera) of Venezuela. Revista de la Faculdad de Agronomia (Maracay) VII, 2: 5-107.

Spencer, K.A. 1983. Leaf mining Agromyzidae (Diptera) in Costa Rica. Revista de Biologia Tropical 31: 41-67.

Spencer, K.A. 1990. Host specialization in the world Agromyzidae (Diptera). Series Entomologica, Vol. 45. Dordrecht, Kluwer Academic Publishers, $440 \mathrm{p}$.

Spencer, K.A., Martinez, M. \& Etienne, J. 1992. Les Agromyzidae (Diptera) de Guadeloupe. Annales de la Société Entomologique de France (Nouvelle série) 28: 251-302.

Spencer, K.A. \& Stigmaier, C.E. 1973. Agromyzidae of Florida with a Supplement on Species from the Caribbean. Arthropods of Florida and Neighboring Land Areas 7: 1-205.

Stevens, P.F. 2001. Angiosperm Phylogeny Website. Version 12. Available at: http:/ /www.mobot.org/MOBOT/research/Ap-web/ (Accessed 7 August 2012).

Stuckenberg, B.R. 1999. Antennal evolution in the Brachycera (Diptera), with a reassessment of terminology relating to the flagellum. Studia Dipterologica 6: 33-48. 